\title{
Evaluasi Hasil Pemodelan Batimetri dari Tiga Kombinasi Lima Satelit Altimetri Pada Laut Natuna dan Laut Sulawesi
}

\author{
ASSESSMENTS ON THE BATHYMETRY MODELING RESULTS FROM THREE \\ Combinations of Five Altimetry Satellites in Natuna aNd SUlaWeSI \\ SEAS
}

\author{
Yustisi A. Lumban-Gaol ${ }^{1 *}$, Nadya Oktaviani ${ }^{1}$, Prayudha Hartanto ${ }^{1}$, Ibnu Sofian ${ }^{2}$ \\ ${ }^{1}$ Pusat Penelitian, Promosi, dan Kerja Sama, Badan Informasi Geospasial, J1. Raya Jakarta-Bogor Km 46 \\ Cibinong 16911, Indonesia \\ ${ }^{2}$ Pusat Kelautan dan Lingkungan Pantai, Badan Informasi Geospasial \\ *Pos el: yustisi.ardhitasari@big.go.id
}

\begin{tabular}{l}
\hline $\boldsymbol{A} \boldsymbol{R} \boldsymbol{T}$ I C L E I N F O \\
\hline Article history \\
Received date \\
24 October 2018 \\
Received in revised form date \\
26 August 2020 \\
Accepted date \\
21 November 2020 \\
Available online date \\
November 2020
\end{tabular}

\begin{tabular}{l}
\hline Kata kunci: \\
\hline \hline Altimetri \\
Anomali gayaberat \\
Batimetri \\
Least square collocation \\
Gravity geological method
\end{tabular}

\begin{abstract}
Indonesia is an archipelago country where $77 \%$ of its territory is waters. National marine mapping has been carried out based on depth measurement data obtained using echosounders. However, this method requires a lot of time and cost. One solution to provide Indonesian bathymetry data is by utilizing altimetry satellite data to model the bathymetry of the seafloor. This study aims to evaluate bathymetric model generated from three combinations of five altimetry satellites in shallow and deep seas. We use least square collocation gravity anomaly and geological gravity for bathymetry modeling. The results of the model show variations in deviations with sounding data available at the Geospatial Information Agency (BIG). The resulting residual trend differs between shallow and deep sea. The optimum results in shallow area is obtained by the combination of Cryosat-2, Jason-1/C, and SARAL while in deep area is obtained by the combination of ERS-1/E-F and Geosat GM. In general, the bathymetry model produced in this study has a similar profile with the sounding data.
\end{abstract}

Keywords: Altimetry, Gravity anomaly, Bathymetry, Least square collocation, Gravity geological model

(C) 2020 Widyariset. All rights reserved 


\section{PENDAHULUAN}

Indonesia adalah negara kepulauan yang wilayahnya didominasi oleh perairan. Berdasarkan Rujukan Nasional Data Kewilayahan Republik Indonesia, luas total perairan Indonesia adalah 6,4 juta $\mathrm{km}^{2}$ dari luas total 8,3 juta $\mathrm{km}^{2}$. Dengan kata lain, $77 \%$ wilayah Indonesia merupakan perairan yang terdiri dari perairan pedalaman dan kepulauan, laut teritorial, zona tambahan, dan zona ekonomi eksklusif. Oleh karena itu, wilayah perairan menjadi salah satu sumber daya yang perlu dioptimalkan. Pengelolaan sumber daya tidak lepas dari kebutuhan akan ketersediaan data geospasial. Data geospasial yang dimaksud adalah data yang berkaitan dengan informasi kedalaman di bawah air, khususnya wilayah pesisir hingga laut lepas. Informasi ini penting untuk digunakan dalam perencanaan wilayah pesisir, pembangunan pelabuhan, hingga penentuan alur pelayaran. Badan Informasi Geospasial (BIG) bergerak dalam bidang geospasial yang menyangkut seluruh aspek keruangan baik darat maupun laut. Salah satu pekerjaan BIG adalah melakukan pemetaan kelautan dan lingkungan pantai. Saat ini penyediaan data geospasial kelautan di BIG sendiri masih menggunakan metode konvensional, yaitu pendugaan menggunakan rambu untuk perairan dangkal, sounding singlebeam dan multibeam untuk wilayah perairan dalam. Metode ini tentunya membutuhkan waktu, biaya, dan sumber daya manusia yang banyak sehingga untuk pemetaan skala menengah hingga skala besar masih belum dilakukan secara menyeluruh di wilayah perairan Indonesia.

Menjawab tantangan akan ketersediaan data geospasial tersebut, model batimetri nasional menjadi salah satu solusi yang bisa dipertimbangkan. Batimetri nasional dibangun dengan menggunakan data dari satelit altimetri. Sistem satelit altimetri yang sudah berkembang sejak tahun 1975 awalnya memiliki misi untuk melakukan pemantauan kondisi laut secara global, sehingga biasanya dimanfaatkan untuk mempelajari perubahan iklim, monitoring arus maupun karakteristik laut, mempelajari interaksi antara laut dan atmosfer, dan menilai perilaku muka air (Cipollini \& Snaith, 2015). Seiring berjalannya waktu, teknologi ini kemudian dimanfaatkan untuk memodelkan dan sekaligus validasi kedalaman laut. Konsep dasar dalam pemodelan batimetri menggunakan data altimetri adalah dengan menghitung komponen anomali gaya berat yang dapat diturunkan dari data satelit altimetri. Anomali gaya berat secara tidak langsung berkaitan dengan relief dasar perairan sehingga dapat digunakan untuk menghitung kedalaman secara matematis.

Penelitian sebelumnya yang berkaitan dengan pemodelan batimetri menggunakan data altimetri pernah dilakukan oleh Calmant and Baudry (1996), Smith and Sandwell (1997), Smith and Sandwell (2004), Smith, Sandwell, and Raney (2005), Hell and Jakobsson (2011), Hsiao et al. (2011), Sandwell et al. (2014), Musthafa (2014), Hsiao et al. (2016).

Calmant and Baudry (1996) melakukan review terhadap beberapa literatur yang melakukan pemetaan batimetri dan feature dasar laut. Penelitian yang di-review memiliki skema dan metode yang berbeda. Misalnya, dalam membuat model bathymetry 2D menggunakan beberapa metode, yaitu dengan melakukan pengaturan langsung pada profil laut, menggunakan linier filter dengan domain Fourier, dan menggunakan non-linier filtering dengan domain Fourier atau luar angkasa. Hasilnya keterbatasan dalam penentuan profil batas laut serta ekstraksi metode dari 1D menjadi 2D membuat model yang dihasilkan memiliki tingkat akurasi yang rendah. Sedangkan metode dengan menggunakan defleksi vertikal 
(linier atau non-linier) untuk memprediksi features bawah laut menjadi metode yang masuk akal dengan beberapa parameter tambahan agar hasilnya mendekati kondisi sebenarnya.

Smith and Sandwell (2004) melakukan penelitian tentang pengukuran batimetri menggunakan satelit altimetri. Pemanfaatan data satelit altimetri bertujuan untuk mendapatkan data batimetri secara global yang diukur dari permukaan laut. Walaupun kelemahan dari metode ini tidak mengamati dasar laut secara langsung, tetapi metode ini dapat digunakan untuk mengisi kekosongan data yang tidak bisa diukur dengan pengukuran secara teristris. Dibutuhkan data anomali gaya berat untuk mendefinisikan topografi dasar laut. Hal ini dikarenakan bahwa gaya berat di permukaan laut dapat digunakan untuk menghitung defleksi vertikal hingga dasar laut. Model anomali gaya berat ini juga mudah digunakan untuk mendefinisikan dasar laut, karena dapat diuji dengan pengukuran teristris menggunakan alat gravimeter. Hasilnya, estimasi kedalaman yang dimodelkan memiliki resolusi setengah dari panjang gelombang sekitar $15 \mathrm{~km}$, sedangkan kesalahan vertikal berkisar 125 hingga $250 \mathrm{~m}$.

Charette and Smith (2010) mengestimasi volume lautan dan menyatakan bahwa faktor utama yang memengaruhi hasil estimasi adalah nilai kedalaman rata-rata. Sementara itu, pengukuran menggunakan echosounder baru mencakup tidak lebih dari $10 \%$ area perairan dunia sehingga dilakukan kajian menggunakan data altimetri untuk mengestimasi volume lautan. Hasil estimasi dengan data altimetri menunjukkan volume lautan yang lebih kecil dibandingkan data sounding. Selisih volumenya setara dengan 500 kali kedalaman Great Lakes atau lima kali Teluk Meksiko.
Musthafa (2014) melakukan penelitian menggunakan misi geodetik pada satelit TOPEX/Poseidon. Satelit ini memiliki panjang pulse 3,125 nsec dan melintas setiap 9,9125 hari. TOPEX/Poseidon mengorbit pada ketinggian $1.335 \mathrm{~km}$ dengan resolusi horizontal $25 \mathrm{~km}$. Hasil analisis yang dilakukan oleh Musthafa (2014) adalah informasi ketinggian permukaan laut yang relatif terhadap sistem referensi tertentu, dalam hal ini geoid atau ellipsoid, yang digunakan untuk mendapatkan informasi kedalaman laut.

Hsiao et al. (2016) melakukan kajian menggunakan data satelit altimetri untuk mendapatkan data kedalaman laut. Penelitiannya melibatkan data gaya berat untuk menurunkan nilai kedalaman dari data ketinggian permukaan laut yang didapat dari perekaman satelit altimetri. Hasil penelitian menunjukan bahwa terdapat perbedaan 6-mgal RMS hasil ukuran di perairan dangkal dengan menggunakan data anomali gaya berat resolusi satu menit. Sementara itu, untuk wilayah Laut China Selatan, pengukuran dengan menggunakan multibeam dengan data estimasi menggunakan satelit altimetri memiliki akurasi sebesar seratus meter. Tingkat ketelitian untuk pengukuran garis pantai menggunakan citra satelit yang dibandingkan berkisar $50-90 \%$ pada 41 dari 44 atol yang jadi objek.

Berdasarkan penelitian tersebut di atas, maka penelitian ini difokuskan untuk membandingkan hasil estimasi kedalaman dengan data satelit altimetri pada tingkat kedalaman laut yang berbeda. Hasilnya diharapkan dapat memberikan kontribusi untuk pemodelan batimetri seluruh Indonesia. 


\section{METODE}

\section{Satelit Altimetri}

Prinsip dasar satelit altimetri adalah mengukur waktu tempuh radiasi gelombang mikro yang dipancarkan oleh satelit hingga diterima kembali setelah menyentuh permukaan air. Waktu tempuh tersebut digunakan untuk menghitung jarak (range) satelit ke permukaan air (Gambar 1). Dalam upaya memperoleh memperoleh nilai Sea Surface Height (SSH) yang akurat, maka diperlukan koreksi pada Range hasil ukuran altimetri. Koreksi adalah akibat kesalahan alat atau dikenal dengan istilah sea state bias (ssb), efek atmosfer, ionosfer, tide loading, dan earth loading. Nilai SSH inilah yang akan digunakan untuk menghitung anomali gaya berat dan kemudian memodelkan batimetri.

Satelit altimetri Seasat diluncurkan pada tahun 1978. Setelah itu, beberapa satelit altimetri lainnya beroperasi aktif hingga saat ini terdapat tujuh satelit yang beroperasi. Setiap satelit memiliki parameter orbit yang beragam. Terdapat dua jenis misi satelit altimetri. Pertama, Exact Repeat Mission (ERM) perekaman data dilakukan secara berulang pada interval tertentu. Kedua, Geodetic Mission (GM) Kedua, pengukuran GM hanya dilakukan

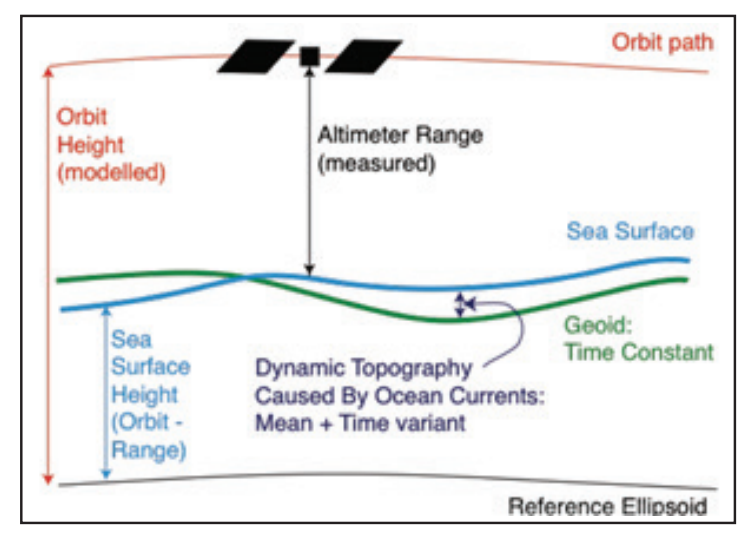

Sumber: Cipollini and Snaith, 2015

Gambar 1. Pengukuran satelit altimetri satelit hanya melakukan pengukuran satu kali atau memiliki interval yang panjang. Konsekuensinya, satelit altimetri tipe ERM memiliki resolusi spasial rendah atau data yang lebih jarang dibandingkan GM.

\section{Defleksi Vertikal dan Anomali Gaya berat}

Nilai SSH altimetri mengacu pada ellipsoid dan mengandung informasi undulasi geoid (N), Sea Surface Topography (SST), beserta eror (e). Geoid N yang telah dihilangkan (di-remove) komponen gelombang panjangnya (NREF) akan menghasilkan geoid residual $(\Delta \mathrm{N})$. Geoid residu tersebut mendeskripsikan pengaruh lapisan bumi dalam, seperti batimetri dan anomali litosfer (Bhattacharyya \& Majumdar, 2006).

Begitu pun dengan SST, mengandung nilai Mean Dynamic Topography (MDT) beserta dinamika SST atau disebut Dynamic Ocean Topography (DOT). MDT merupakan perbedaan elevasi antara geoid dengan Mean Sea Surface (MSS), MSS dapat diperoleh dari nilai rata-rata data SSH altimetri ERM. Pada terminologi data ukuran pasang surut, MSS memiliki profil yang sama dengan Mean Sea Level (MSL) tetapi berbeda dalam hal bidang referensi. Nilai SSH dapat dinyatakan dengan persamaan:

$\mathrm{SSH}=\mathrm{N}_{\mathrm{REF}}+\Delta \mathrm{N}+\mathrm{MDT}+\mathrm{DOT}+\mathrm{e}$

Pada gelombang panjang, NREF, MDT, dan DOT memiliki nilai yang kurang lebih sama antara dua titik altimetri yang berdekatan dalam satu track (along-track) sehingga residual $\Delta \mathrm{N}$ akan identik dengan selisih tinggi SSH antara dua titik altimetri yang berdekatan dan dapat dinyatakan dalam persamaan berikut:

$\mathrm{SSH}_{2}-\mathrm{SSH}_{1}=\Delta \mathrm{N}_{2}-\Delta \mathrm{N}_{1}+\mathrm{e}$ 
Nilai along-track residual $\Delta \mathrm{N}$ sama dengan geoid slope dimana geoid slope berkaitan dengan defleksi vertikal (DOV) ke arah utara dan timur $(\xi, \eta)$. Along-track DOV memiliki nilai yang sama dengan geoid gradien, namun memiliki arah yang berlawanan. Dari persamaan 2, alongtrack DOV (E) dapat dinyatakan dengan persamaan:

$\varepsilon=(\mathrm{SSH} 2-\mathrm{SSH} 1) / \mathrm{d}$

Dari persamaan diatas, $\mathrm{d}$ adalah jarak antar-titik pengamatan yang berdekatan. Nilai DOV lebih sedikit mengandung eror dari gelombang panjang dibandingkan tinggi $\Delta \mathrm{N}$. Hal ini dikarenakan sinyal gelombang panjang, baik tinggi geoid $\mathrm{N}$ maupun DOT, tidak perlu dimodelkan karena memiliki nilai yang identik pada titik yang berdekatan (Andersen, 2013). Selain eror akibat pengaruh gelombang panjang, sumber kesalahan pada nilai DOV adalah kesalahan trunkasi dan pengaruh gangguan gaya berat (gravity disturbance). Penjelasan lengkap mengenai sumber kesalahan pada nilai DOV dapat ditemukan dalam penelitian Jekeli (Jekeli, 1999).

Residual geoid gradien (along-track DOV) ini kemudian digunakan untuk menghitung anomali gaya berat. Pemodelan anomali gaya berat dari satelit altimetri dapat dilakukan dengan dua pendekatan, yaitu stokastik dan deterministik. Pendekatan stokastik menghitung nilai anomali gaya berat dari data gradien gaya berat menggunakan algoritma least-squares collocation (LSC). Sementara itu, pendekatan metode deterministik menggunakan algoritma Inverse Vening-Meinesz (IVM) yang dapat menghitung anomali gaya berat secara langsung dari data DOV. Berdasarkan penelitian yang dilakukan oleh Hartanto et al. (2018), ketelitian model anomali gaya berat dengan algoritma IVM lebih rendah dibanding algoritma LSC. Oleh karena itu, penelitian ini meggunakan pendekatan stokastik dengan algoritma Least-Squares Collocation (LSC) berdasarkan Hwang and Parsons, 1996.

$\Delta \mathrm{g}=\mathrm{C}_{\Delta \mathrm{g} \varepsilon}\left(\mathrm{C}_{\varepsilon \varepsilon}+\mathrm{D}_{\varepsilon \varepsilon}\right)^{-1} \varepsilon$

$\mathrm{C}_{\Delta \mathrm{g} \varepsilon}, \quad \mathrm{C}_{\varepsilon \varepsilon}$, dan $\mathrm{D}_{\varepsilon \varepsilon}$ masing-masing adalah matriks kovariansi anomali gaya berat - residual geoid gradien, residual geoid gradien - residual geoid gradien, dan variansi noise dari residual geoid gradien.

\section{Pemodelan Batimetri}

Pemodelan batimetri berdasarkan nilai anomali gaya berat dilakukan menggunakan metode Gravity Geological Model (GGM) dengan mengaplikasikan termin Bouguer $2 \pi \mathrm{G} \Delta \rho\left(\mathrm{d}_{\text {ref }}(\mathrm{i})-\mathrm{D}\right)$, dimana $\mathrm{G}$ adalah konstanta gravitasi $\left(6.672 \times 10^{-8}\right.$ $\left.\mathrm{cm}^{3} / \mathrm{gs}^{2}\right), \Delta \rho$ perbedaan antara massa jenis air laut dan lapisan batuan padat di dasar laut dengan nilai $1.64 \mathrm{~cm}^{3} / \mathrm{g}$, D merupakan nilai kedalaman yang paling dalam $(500 \mathrm{~m}$ untuk perairan Natuna dan 7.000 m untuk Laut Sulawesi), dan $d_{\text {ref }}$ adalah referensi kedalaman berdasarkan global batimetri ETOPO1. Penjelasan lengkap mengenai metode GGM untuk membuat model batimetri dapat ditemukan dalam Y. Hsiao et al. (2011), Y. S. Hsiao et al. (2016), Kim et al. (2011).

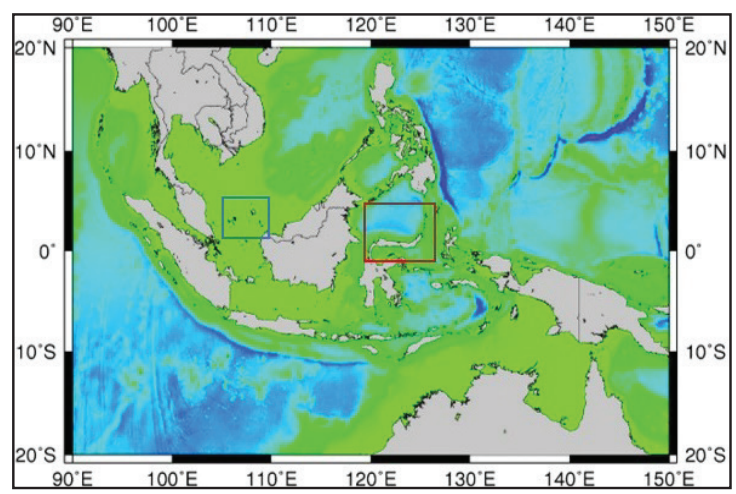

Gambar 2. Lokasi penelitian, kotak biru adalah perairan Natuna dan kotak merah adalah Laut Sulawesi 


\section{Data dan Lokasi Penelitian}

Lokasi penelitian ini dibagi menjadi dua, yaitu perairan Kepulauan Natuna dan Laut Sulawesi (Gambar 2). Lokasi ini dipilih berdasarkan pertimbangan ketersediaan data suvei batimetri dan variasi kedalamannya dimana Laut Sulawesi mewakili perairan dalam sedangkan Natuna mewakili perairan dangkal.

Batasan geografis yang diambil pada perairan Natuna adalah $104^{\circ}-110^{\circ} \mathrm{BT}$ dan $0^{\circ}-6^{\circ}$ LU. Pada Laut Sulawesi lokasi penelitian terletak pada $119^{\circ}-127^{\circ} \mathrm{BT}$ dan $2^{\circ} \mathrm{LS}-6^{\circ} \mathrm{LU}$. Data yang digunakan pada penelitian ini adalah SSH yang dikompilasi dari server rads, EGM2008 sampai dengan 2160 derajat, MDT DTU10 (DTU, 2018), trackline gaya berat NGDC, survei batimetri (BIG), dan model global ETOPO1. Misi satelit altimetri yang digunakan antara lain ERS-1 Phase E dan F, Geosat GM, Cryosat-2, Jason-1 Phase C, dan SARAL GM.

\section{Metodologi Penelitian}

Penelitian terbagi menjadi tiga skenario pada kombinasi satelit yang digunakan (Tabel 1). Satelit dikelompokkan berdasarkan generasinya dimana ERS-1 dan Geosat merupakan satelit pendahulu tipe GM sehingga dipilih menjadi satu skenario. Kombinasi lainnya merupakan

Tabel 1. Skenario penelitian

\begin{tabular}{cl}
\hline Skenario & \multicolumn{1}{c}{ Satelit } \\
\hline 1 & Cryosat-2 \\
& Jason-1/C \\
& SARAL \\
& Cryosat-2 \\
& Jason-1/C \\
& SARAL \\
& ERS-1/E-F \\
& Geosat GM \\
& ERS-1/E-F \\
& Geosat GM \\
\hline
\end{tabular}

gabungan dari beberapa satelit lainnya dan semua satelit.

Masing-masing skenario dilakukan pada kedua lokasi penelitian. Model batimetri akan memiliki resolusi 1 menit $(\sim 1.85 \mathrm{~km})$ sehingga semua data yang dibutuhkan akan menggunakan resolusi yang sama.

Secara umum, alur penelitian ini disajikan pada Gambar 3. Tahap awal penelitian ini adalah menghitung nilai residual geoid gradien setiap satelit. Seperti telah disebutkan sebelumnya bahwa penelitian ini terbagi menjadi tiga skenario. Akan tetapi, untuk melihat distribusi rms setiap satelit terhadap NGDC, anomali gaya berat setiap satelit dihitung terlebih dahulu. Setelah itu, nilai residual geoid gradien setiap satelit dikombinasikan sesuai skenario. Gridding anomali gaya berat dilakukan menggunakan metode LSC dengan ukuran 1'x 1'. Terminologi Bouguer diterapkan pada model anomali gaya berat untuk memodelkan batimetri. Model anomali gaya berat dan batimetri dari satelit altimetri ini kemudian divalidasi untuk melihat nilai rms. Data trackline gaya berat NGDC digunakan sebagai validator model anomali gaya berat dan data survei batimetri milik BIG digunakan untuk validasi model batimetri.

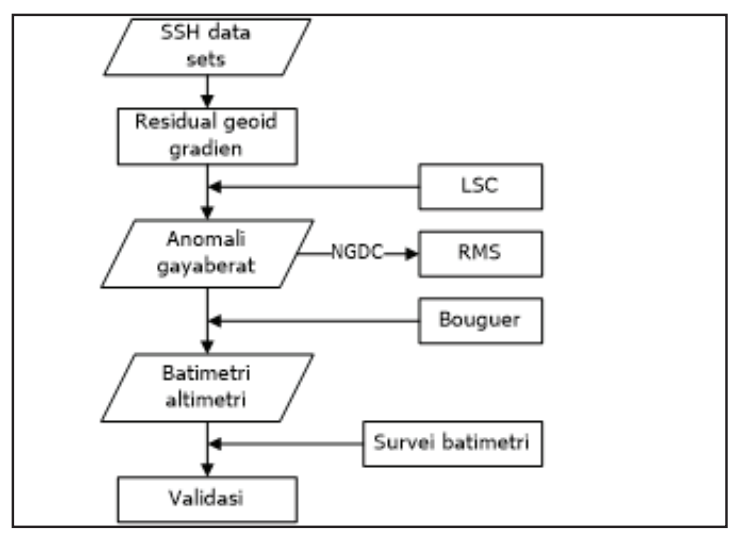

Gambar 3. Alur kerja penelitian pemodelan batimetri menggunakan data altimetri 
Tabel 2. Distribusi nilai rms anomali gayaberat terhadap trackline NGDC.

\begin{tabular}{lcc}
\hline \multicolumn{1}{c}{ Satelit } & \multicolumn{2}{c}{ RMS (mgal) } \\
& Natuna & Sulawesi \\
\hline Per Satelit & & \\
SARAL & 7,07 & 8,90 \\
ERS-1/GM & 7,23 & 8,93 \\
Jason-1/C & 7,30 & 8,97 \\
ERS-2 & 7,08 & 9,02 \\
Cryosat-2 & 6,85 & 9,10 \\
Geosat-Follow on & 7,32 & 9,31 \\
Geosat & 7,16 & 9,27 \\
Kombinasi Satelit & & \\
Skenario 1 & 6,94 & 9,07 \\
Skenario 2 & 6,91 & 9,06 \\
Skenario 3 & 7,04 & 8,97 \\
\hline
\end{tabular}

Tabel 3. Nilai rms dan standar deviasi model batimetri terhadap survei batimetri.

\begin{tabular}{ccccc}
\hline Kombinasi & \multicolumn{2}{c}{ Natuna } & \multicolumn{2}{c}{ Sulawesi } \\
Satelit & RMS & STDEV & RMS & STDEV \\
\hline Skenario 1 & 4,99 & 12,22 & 25,68 & 327,65 \\
Skenario 2 & 7,03 & 23,01 & 25,27 & 316,53 \\
Skenario 3 & 9,23 & 34,06 & 22,61 & 255,55 \\
\hline
\end{tabular}

\section{HASIL DAN PEMBAHASAN}

Nilai RMS anomali gaya berat setiap satelit berkisar pada 7-9 mgal untuk kedua lokasi penelitian. Sementara itu, anomali gaya berat dari masing-masing skenario memberikan hasil dengan ketelitian yang beragam setelah dibandingkan dengan data NGDC (Tabel 3). Untuk perairan dangkal yang diwakili oleh perairan Natuna, skenario 2 memberikan nilai rms paling kecil sebesar 6,91 mgal. Sementara itu, pada Laut Sulawesi, hasil terbaik diberikan oleh skenario 3 dengan rms 8,97 mgal. Hasil ini mengindikasikan bahwa kombinasi satelit memberikan hasil yang berbeda pada perairan dangkal dan dalam.

Selanjutnya, hasil model batimetri yang dibentuk dari kombinasi satelit pun memberikan nilai rms dan standar deviasi yang beragam setelah divalidasi terhadap data survei batimetri. Kombinasi satelit Cryosat-2, Jason-1/C dan SARAL (Tabel 4) memberikan nilai rms paling minimum pada Laut Natuna. Sementara itu, rms minimum pada laut Sulawesi diperoleh dari kombinasi satelit ERS-1/E-F dan Geosat GM. Hal ini sejalan dengan hasil pada anomali gaya berat. Jika anomali gaya berat memberikan nilai RMS minimum, maka akan memberikan model batimetri dengan nilai rms minimum juga.

Hasil gridding anomali gaya berat dan batimetri menunjukkan perbedaan antara ketiga kombinasi yang diterapkan. Pada perairan Natuna, dapat terlihat perbedaan pola dan range nilai anomali gaya berat Gambar 4 bawah dibandingkan dengan Gambar 4 lainnya. Hasil kombinasi antara satelit GM pendahulu, yaitu ERS-1/E-F dan Geosat GM memiliki tekstur yang bergelombang menyerupai kulit jeruk, disebut efek kulit jeruk (orange skin effect), akibat masih terdapat kesalahan dari dinamika permukaan laut. Efek kulit jeruk ini tidak tampak lagi pada model batimetri. Akan tetapi, validasi terhadap data perum menunjukkan nilai penyimpangan sampai dengan 34,06 meter.

Faktor lain yang memengaruhi kualitas anomali gaya berat adalah matriks kovariansi yang digunakan. Penelitian ini menggunakan model kovariansi global untuk area Indonesia. Agar memperoleh hasil lebih baik, matriks kovariansi dapat dimodelkan secara tersendiri untuk area perairan Indonesia, atau secara khusus dalam penelitian ini adalah Laut Natuna dan Laut Sulawesi.

Gambar 5 menampilkan model batimetri pada Laut Natuna dengan rentang kedalaman hingga $500 \mathrm{~m}$. Berdasarkan model, nilai kedalaman maksimal untuk masing-masing skenario memiliki perbedaan yang signifikan (Gambar 6). Skenario pertama memiliki kedalaman maksimal 207 $\mathrm{m}$, skenario kedua $685,33 \mathrm{~m}$, dan skenario ketiga 805,82 m. Jika melihat persebaran data perum di Natuna (Gambar 7) yang berlokasi di sekitar Pulau Natuna dan Bintan, maka artinya data perum berada pada 

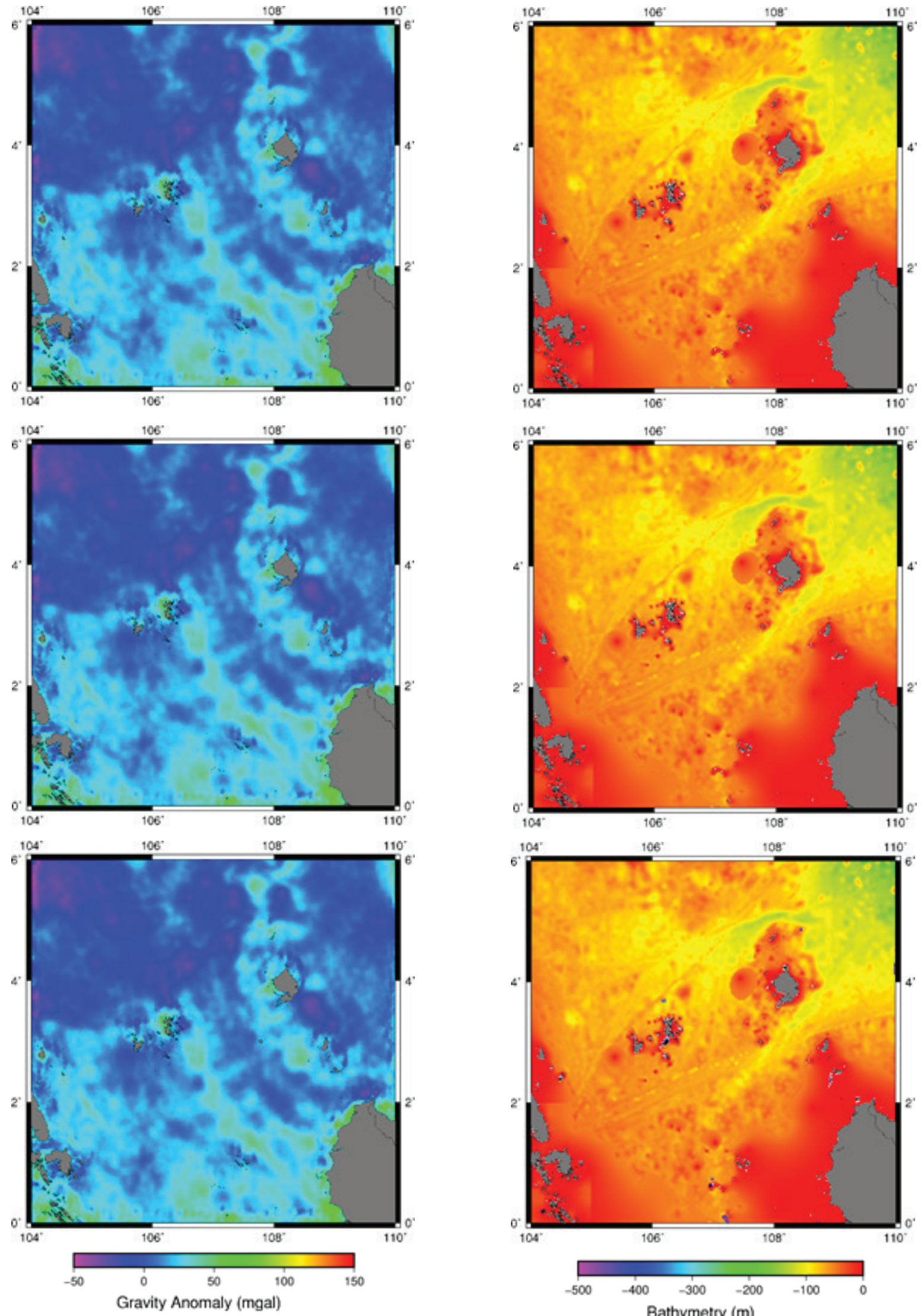

Gambar 4. Hasil anomali gaya berat skenario 1 (atas), skenario 2 (tengah), dan skenario 3 (bawah) pada Laut Natuna

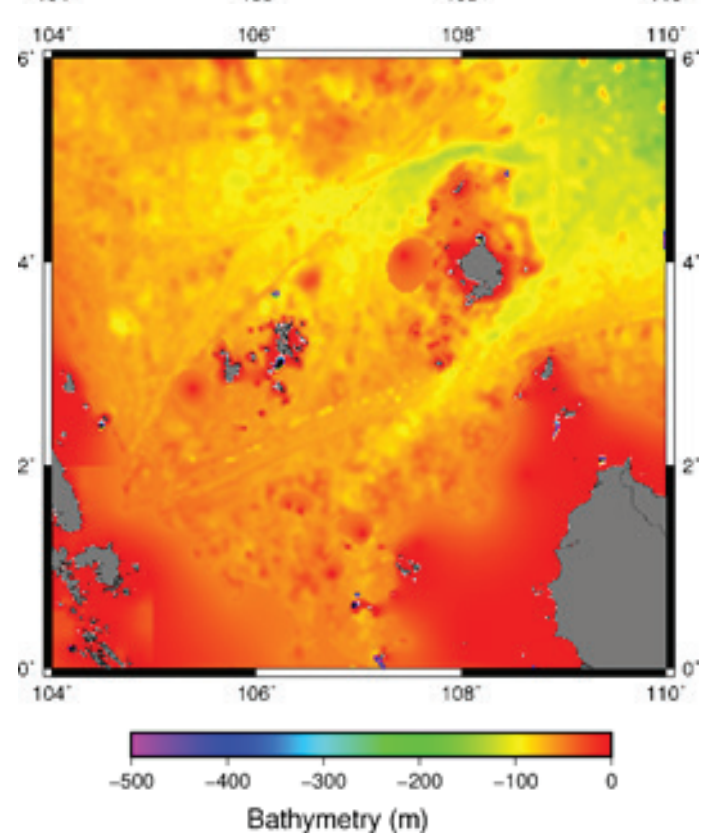

Gambar 5. Hasil pemodelan batimetri skenario 1 (atas), skenario 2 (tengah), dan skenario 3 (bawah) pada Laut Natuna 


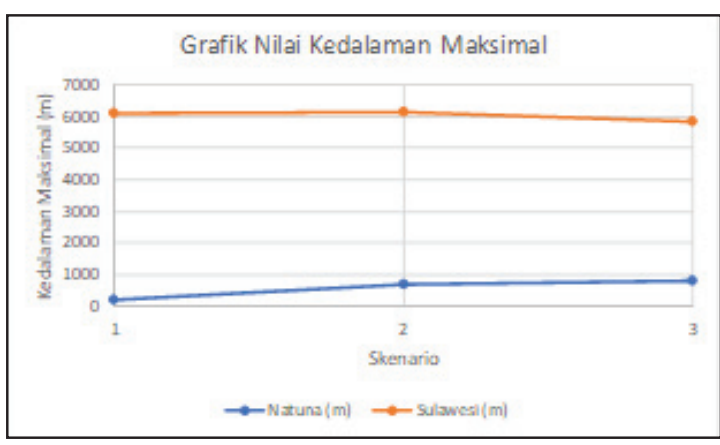

Gambar 6. Grafik nilai kedalaman maksimal pada Laut Natuna dan Sulawesi untuk masing-masing skenario

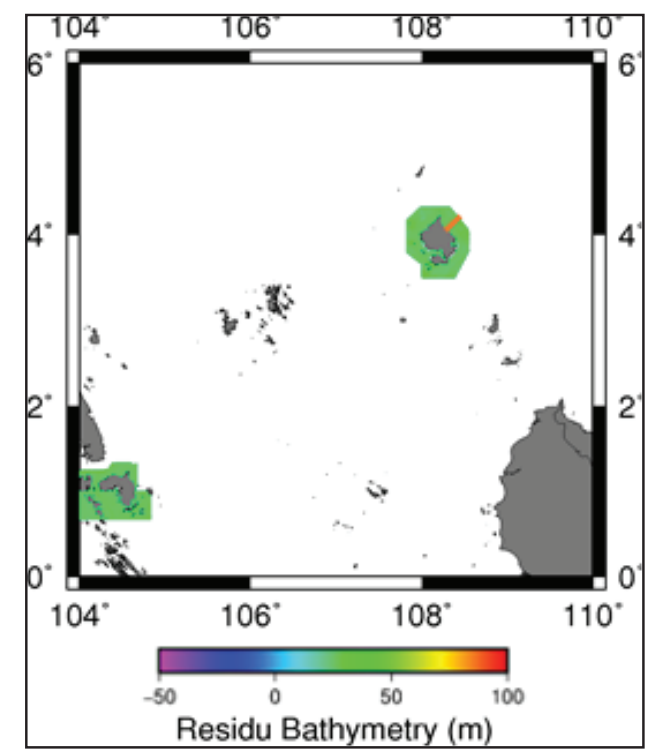

Gambar 7. Residu model batimetri skenario 1 dengan data perum pada Laut Natuna. Garis oranye adalah lokasi profil melintang

area pesisir (shallow water) sehingga nilai penyimpangan tersebut cukup signifikan.

Namun, satelit altimetri memiliki kelemahan di area pesisir karena sinyal yang dikirimkan oleh satelit memiliki eror akibat pengaruh sinyal menyentuh daratan. Untuk mendapatkan hasil validasi yang lebih komperhensif, diperlukan data perum pada area Laut Tiongkok Selatan. Akan tetapi, data tersebut belum tersedia.

Gambar 8a menampilkan profil melintang antara data model dan data perum pada perairan Pulau Natuna area timur laut.

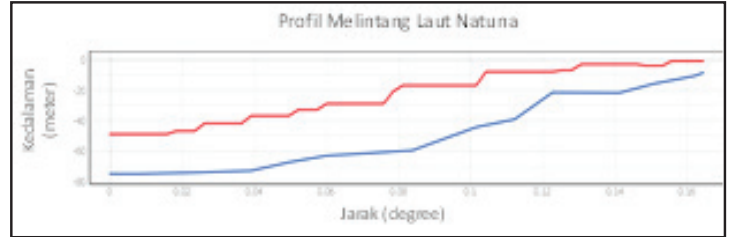

(a)

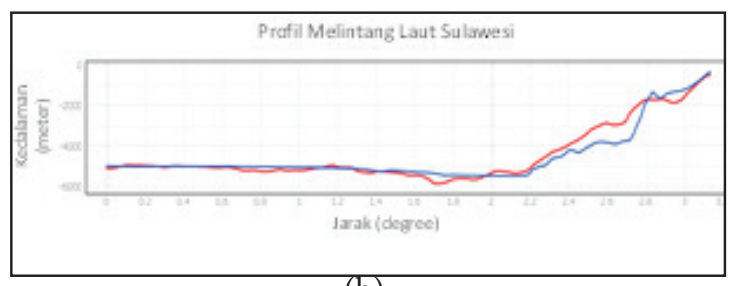

(b)

Gambar 8. Profil melintang pada sampel area di (a) Laut Natuna dan (b) Sulawesi. Garis merah adalah data model batimetri dan biru adalah data perum

Profil ini menunjukkan perbedaan antara kedalaman dari kedua data tersebut dimana data perum memiliki nilai kedalaman lebih besar. Akan tetapi, keduanya memiliki profil atau pola yang sama, yaitu semakin menjauhi area pesisir datanya semakin dalam.

Pada Laut Sulawesi (Gambar 9), rentang nilai anomali gaya berat lebih bervariasi dibandingkan Natuna. Hal ini berhubungan dengan model batimetrinya, dimana nilai yang ditunjukkan oleh model (Gambar 10) memiliki variasi kedalaman. Titik terdalam pada model batimetri masing-masing skenario mulai dari yang pertama adalah $6.106,07 \mathrm{~m}, 6.142,07 \mathrm{~m}$, dan 5.856,36 $\mathrm{m}$ dengan rentang standar deviasi antara 255 s.d. 327 meter.

Variasi kedalaman pada Laut Sulawesi juga terlihat pada profil melintangnya (Gambar 8b). Seperti profil melintang pada Laut Natuna, kedua data di Laut Sulawesi juga menunjukkan profil kedalaman yang sama antara model dan data perum.

Gambar 11 menampilkan rentang residu antara kedalaman model dan data di Laut Sulawesi. Data perum yang tersedia di $\mathrm{v}$ merupakan gabungan dari beberapa kegiatan survey menggunakan spesifikasi 

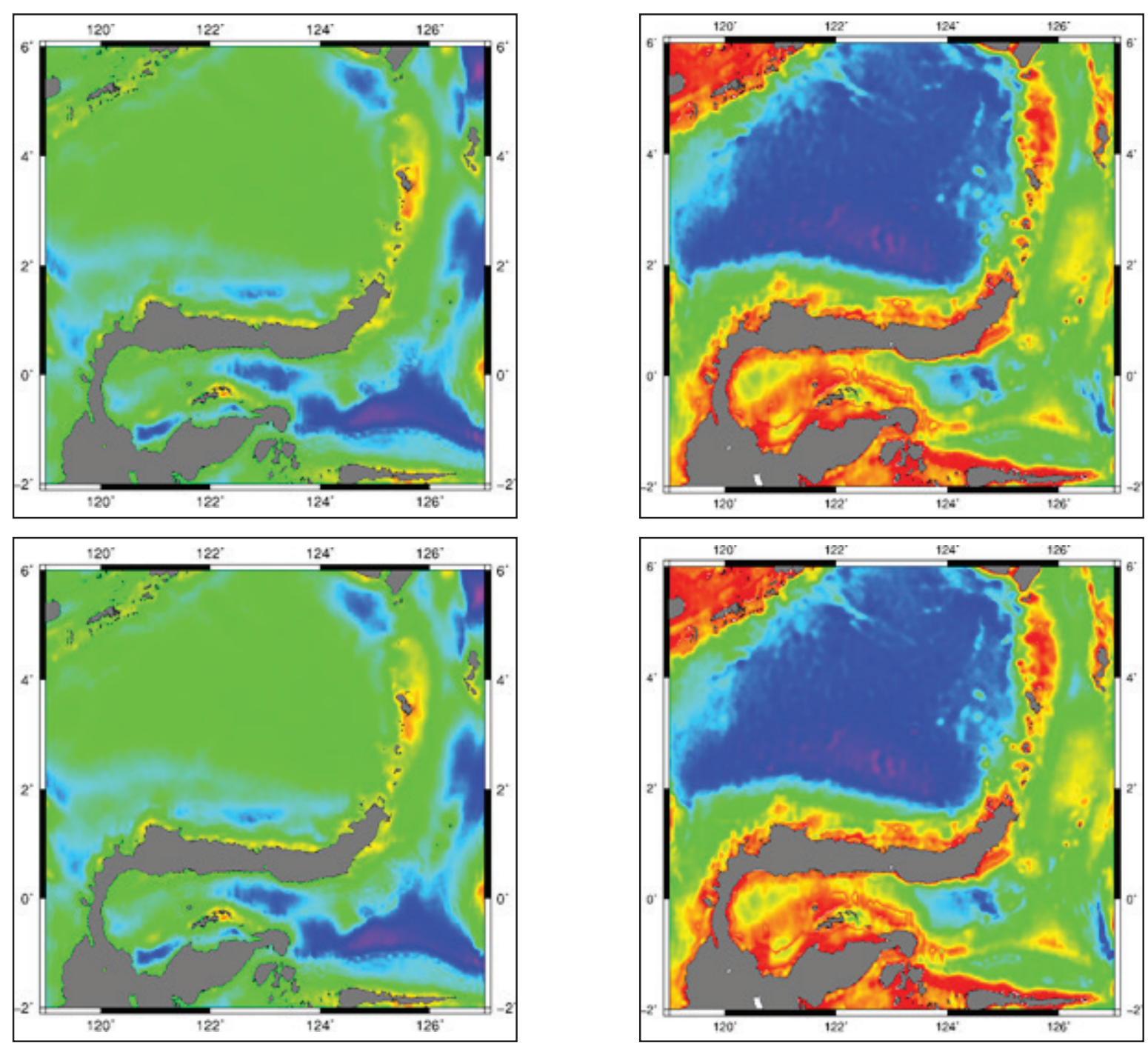

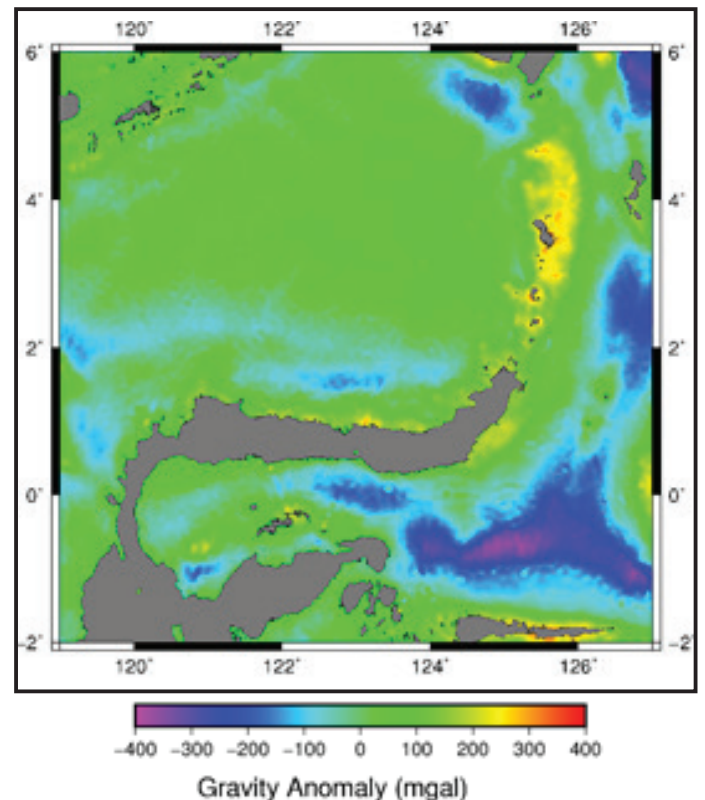

Gambar 9. Hasil anomali gayaberat skenario 1 (atas), skenario 2 (tengah), dan skenario 3 (bawah) pada Laut Sulawesi

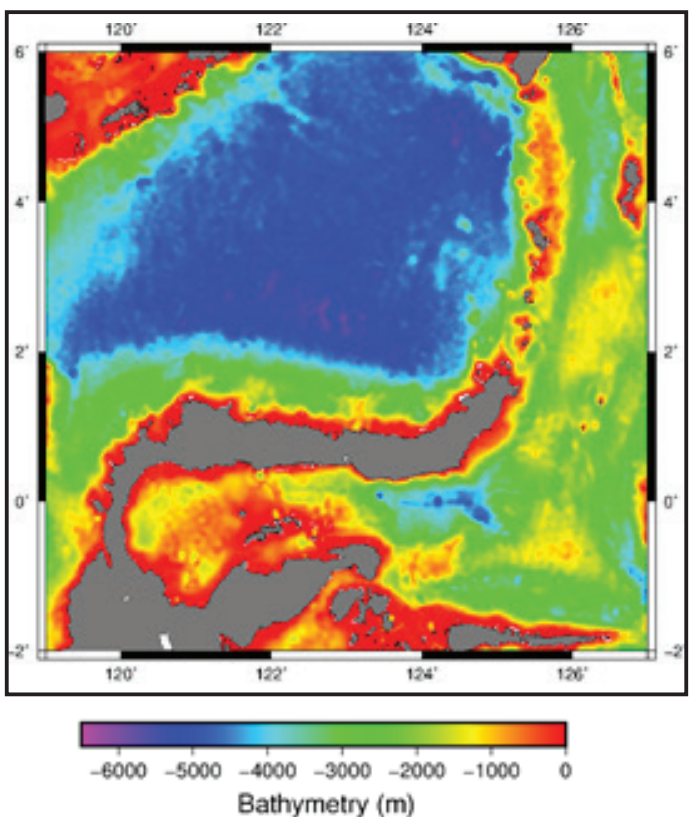

Gambar 10. Hasil pemodelan batimetri skenario 1 (atas), skenario 2 (tengah), dan skenario 3 (bawah) pada Laut Sulawesi 


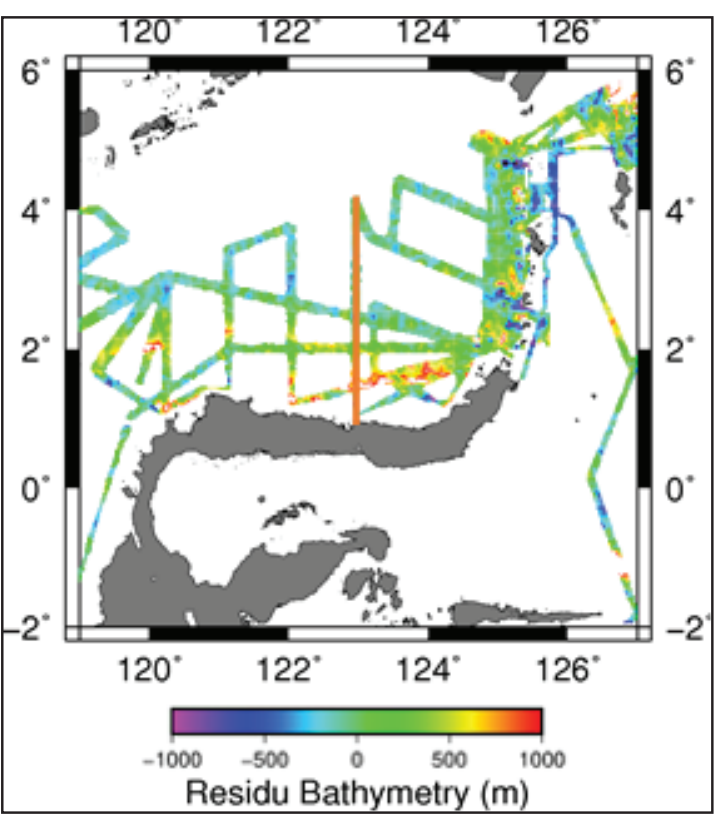

Gambar 11. Residu model batimetri skenario 3 dengan data perum pada Laut Sulawesi. Garis oranye adalah lokasi profil melintang

echosounder yang berbeda-beda. Dari gambar tersebut dapat terlihat pola sebaran residu yang memiliki nilai besar terdapat pada area pesisir. Sementara itu, penyebab perbedaan nilai residu yang signifikan pada line perum belum bisa dipastikan mengingat area tersebut merupakan area laut dalam dan spesifikasi echosounder di sini tidak diketahui.

Berdasarkan hasil model ini, pembangunan model batimetri nasional perlu mempertimbangkan variasi kombinasi satelit menurut kedalaman. Pada penelitian ini, perairan dangkal yang diwakili oleh Natuna mendapatkan model terbaik dari kombinasi satelit Cryosat-2, Jason-1/C dan SARAL. Sementara itu, pada laut dalam yang diwakili oleh area Sulawesi bagian utara, model batimetri terbaik diperoleh dari kombinasi satelit ERS-1/E, ERS-1/F dan Geosat GM.

Parameter yang mempengaruhi akurasi dari model batimetri adalah konstanta perbedaan masa jenis, nilai kedalaman, dan nilai referensi yang digunakan. Penelitian ini menggunakan asumsi bahwa semua kondisi perairan memiliki perbedaan masa jenis yang homogen dan isotropik. Pada dasarnya, pemodelan batimetri menggunakan metode GGM menggunakan model yang tersedia pada proses komputasinya. Oleh karena itu, hasilnya akan bergantung dari model dan parameter yang digunakan.

\section{KESIMPULAN}

Pemodelan batimetri menggunakan satelit altimetri memiliki variasi penyimpangan setelah dibandingkan dengan data perum hasil survei batimetri. Kontribusi penyimpangan ini berasal dari parameter yang digunakan dalam pemodelan anomali gaya berat dan GGM. Kualitas pemodelan anomali gaya berat bergantung pada koreksi-koreksi yang diterapkan, model MDT dan matriks kovariansi yang digunakan. Sementara itu, nilai anomali gaya berat ini sendiri akan memberikan kontribusi terhadap kualitas model batimetri yang dibangun. Dalam upaya optimalisasi model anomali gaya berat, nilai gaya berat dari data trackline NGDC dapat diasimilasikan ke dalam model dengan memperhatikan bias antara altimetri dan NGDC. Selain anomali gaya berat, metode GGM untuk pendefinisian batimetri memiliki beberapa konstanta yang digunakan seperti perbedaan masa jenis, nilai referensi kedalaman, dan asumsi nilai terdalam yang digunakan. Seluruh konstanta ini akan memberikan hasil yang berbeda jika nilainya diubah.

Secara umum, model batimetri yang dihasilkan sudah memiliki pola yang sesuai dengan data perum. Pengembangan model masih dapat dilakukan dengan mengoptimalkan data altimetri pada area pesisir melalui proses koreksi retracking pada data altimetri yang dekat dengan daratan. Selain itu, metode Satellite Derived Bathymetry (SDB) dapat digunakan ke depannya untuk meningkatkan resolusi batimetri pada area pesisir. 


\section{UCAPAN TERIMA KASIH}

BIG dan Kementrian Riset, Teknologi dan Pendidikan Tinggi melalui program Insentif Riset Sistem Inovasi Nasional (INSINAS) Flagship sebagai pemberi dana penelitian. Dr.techn. Dudy D. Wijaya, Kelompok Keahlian Geodesi, Institut Teknologi Bandung yang telah memberikan dukungan teknis.

\section{DAFTAR ACUAN}

Andersen, O. B. (2013). Marine Gravity and Geoid from Satellite Altimetry. In Geoid Determination (pp. 401-451). https://doi.org/10.1007/978-3-54074700-0.

Bhattacharyya, R., \& Majumdar, T. J. (2006). Residual geoid and free-air gravity over the Indian offshore from ERS-1 high resolution altimeter data. Journal of the Indian Society of Remote Sensing, 34(3), 289-298.https:// doi.org/10.1007/BF02990657.

Calmant, S., \& Baudry, N. (1996). Modelling bathymetry by inverting satellite altimetry data: A review. Marine Geophysical Researches, 18(2-4), 123-134. https://doi.org/10.1007/ BF00286073.

Charette, M. A., \& Smith, W. H. F. (2010). The Volume of Earth's Ocean. Journal of The Oceanography Society, 23(2), 112-114.

Cipollini, P., \& Snaith, H. (2015). A short course on Altimetry. Retrieved February 1, 2018, from Esa website: ftp://ftp.ifremer.fr/ifremer/cersat/ OTC2015/

DTU. (2018). DTU Space National Space Institute. Retrieved from ftp://ftp. space.dtu.dk/pub/DTU10/1_MIN/.

Hartanto, P., Huda, S., Putra, W., Variandy, E. D., Triarahmadhana, B., Pangastuti, D., ... Hwang, C. (2018). Estimation of marine gravity anomaly model from satellite altim- etry data (Case Study: Kalimantan and Sulawesi Waters-Indonesia). IOP Conference Series: Earth and Environmental Science, 162(1). https://doi.org/10.1088/17551315/162/1/012038.

Hell, B., \& Jakobsson, M. (2011). Gridding heterogeneous bathymetric data sets with stacked continuous curvature splines in tension. Marine Geophysical Research, 32(4), 493-501. https:// doi.org/10.1007/s11001-011-9141-1

Hsiao, Y., Kim, J. W., Kim, K. B., Lee, B. Y., \& Hwang, C. (2011). Bathymetry Estimation Using the Gravity-Geologic Method: An Investigation of Density Contrast Predicted by the Downward Continuation Method. 22(3), 347-358. https://doi.org/10.3319/ TAO.2010.10.13.01(Oc)1.

Hsiao, Y. S., Hwang, C., Cheng, Y. S., Chen, L. C., Hsu, H. J., Tsai, J. H., ... Kao, Y. C. (2016). High-resolution depth and coastline over major atolls of South China Sea from satellite altimetry and imagery. Remote Sensing of Environment, 176, 69-83. https:// doi.org/10.1016/j.rse.2016.01.016.

Hwang, C., \& Parsons, B. (1996). An optimal procedure for deriving marine gravity from multi-satellite altimetry. Geophysical Journal International, 125(3), 705-718. https://doi. org/10.1111/j.1365-246X.1996. tb06018.x.

Jekeli, C. (1999). An analysis of vertical deflections derived from high-degree spherical harmonic models. Journal of Geodesy, 73(1), 10-22. https://doi. org/10.1007/s001900050213.

Kim, J. W., von Frese, R. R. B., Lee, B. Y., Roman, D. R., \& Doh, S. J. (2011). Altimetry-derived gravity predictions of bathymetry by the gravity-geologic method. Pure and Applied Geophysics, 168(5), 815-826. https://doi.org/10.1007/ s00024-010-0170-5. 
Musthafa, W. N. (2014). Pemanfaatan Satelit Altimetri Untuk Estimasi Batimetri. Institut Teknologi Bandung.

Sandwell, D. T., Müller, R. D., Smith, W. H. F., Garcia, E., \& Francis, R. (2014). New global marine gravity model from CryoSat-2 and Jason-1 reveals buried tectonic structure. Science, 346(6205), 65-67. https:// doi.org/10.1126/science.1258213.

Smith, W. H. F., \& Sandwell, D. T. (1997). Global sea floor topography from satellite altimetry and ship depth soundings. Science, 277(5334), 1956-1962. https://doi.org/10.1126/ science.277.5334.1956.
Smith, W. H. F., Sandwell, D. T., \& Raney, R. K. (2005). Bathymetry from satellite altimetry: Present and future. Proceedings of MTS/IEEE OCEANS, 2005, 2005. https://doi.org/10.1109/ OCEANS.2005.1640160.

Smith, W., \& Sandwell, D. (2004). Conventional Bathymetry, Bathymetry from Space, and Geodetic Altimetry. Oceanography, 17(1), 8-23. https:// doi.org/10.5670/oceanog.2004.63. 